\title{
Spread and Increase of Ratoon Stunting Disease of Sugarcane and Comparison of Disease Detection Methods
}

J. W. Hoy, Department of Plant Pathology and Crop Physiology, Louisiana State University Agricultural Center, Baton Rouge 70803; M. P. Grisham, Sugarcane Research Unit, USDA-ARS-SRRC, Houma, LA 70361; and K. E. Damann, Department of Plant Pathology and Crop Physiology, Louisiana State University Agricultural Center, Baton Rouge 70803

\begin{abstract}
Hoy, J. W., Grisham, M. P., and Damann, K. E. 1999. Spread and increase of ratoon stunting disease of sugarcane and comparison of disease detection methods. Plant Dis. 83:1170-1175.

The spread and increase of ratoon stunting disease (RSD) resulting from two mechanical harvests were compared in eight sugarcane cultivars at two locations. RSD spread and increase were detected in the ratoon crops grown after each harvest and varied among cultivars and locations. Disease spread and increase were greater in plants grown from stalks collected at the first harvest than in the first ratoon growth from the harvested field. RSD infection was determined using five disease detection methods: alkaline-induced metaxylem autofluorescence; microscopic examination of xylem sap; and dot blot, evaporative-binding, and tissue blot enzyme immunoassays. The tissue blot enzyme immunoassay was the most accurate RSD detection method. The dot blot and evaporative-binding enzyme immunoassays were the least sensitive for detection of RSD-infected stalks, and alkaline-induced metaxylem autofluorescence was least accurate for correct identification of noninfected stalks. The results indicate that disease spread and increase are variable even among cultivars susceptible to yield loss due to RSD, and the greatest threat of disease spread and increase occurs at planting.
\end{abstract}

Sugarcane (interspecific hybrids of Saccharum) is vegetatively propagated, and multiple annual harvests of stalks are obtained from a planting. Following the harvest of stalks from the plant cane, or first season crop, a ratoon crop is allowed to develop from the buds on the stubble remaining in the ground. Variable numbers of ratoon crops are obtained in different sugarcane production regions. Two ratoon crops are typically obtained from a planting in Louisiana.

Ratoon stunting disease (RSD), one of the most important diseases of sugarcane worldwide (7), is caused by a xylem-limited bacterium, Clavibacter xyli subsp. xyli. The pathogen can be spread during propagation in infected cuttings from field to field or mechanically on equipment from plant to plant within a field. The titer of bacteria in xylem sap increases during the growing season, so the most important periods of spread occur during planting and harvest. Previous research has shown vari-

Corresponding author: J. W. Hoy

E-mail: jhoy@agctr.lsu.edu

Approved for publication by the director of the Louisiana Agricultural Experiment Station as manuscript 99-38-0308.

Accepted for publication 8 September 1999.

Publication no. D-1999-1022-01R

(C) 1999 The American Phytopathological Society able rates of RSD spread and increase resulting from mechanical harvest $(3,5,7,13)$.

The RSD spread that occurs during each harvest causes disease incidence to increase during the crop cycle. The stunting resulting from infection is more severe when plants are exposed to drought stress. Stunting tends to be progressively more severe in successive ratoon crops $(7,8)$, and RSD can reduce the number of ratoon crops obtained from a planting. To control the disease, it is necessary to obtain and plant healthy stalks and then prevent the introduction of the pathogen. However, RSD causes no visible external symptoms other than stunting, and internal symptoms are not reliable $(7,12)$. This aspect of the disease makes effective management difficult, and considerable research has been devoted to developing reliable assays for detection that would allow disease monitoring $(2,4,6,9,10)$.

The first objective of this study was to determine and compare rates of RSD spread and increase in different cultivars, both within fields along rows and between fields, in plantings established with stalks from harvested spread plots. The second objective was to compare the reliability of different RSD detection methods. Preliminary results have been reported (11).

\section{MATERIALS AND METHODS}

Field experiments. Two experiments were conducted at each of two locations in Louisiana: the Sugar Research Station of the Louisiana Agricultural Experiment
Station at St. Gabriel (location one), and the Ardoyne Research Farm of the USDAARS-SRRC Sugarcane Research Unit at Chacahoula (location two). In the first experiment to study within-field spread and increase of RSD, eight commercial sugarcane cultivars, CP 65-357, CP 70321, CP 72-370, CP 79-318, LCP 82-89, LHo 83-153, LCP 85-384, and HoCP 85845 , were planted. Twenty RSD-free stalks of each cultivar, 2 to $2.5 \mathrm{~m}$ in length, were planted in 15.2-m single-row spread plots. At planting, two stalks were placed in the planting furrow side by side, then the next two were placed with an approximately $20 \%$ overlap. There were three replicate plots per cultivar planted in a completely randomized design. An inoculum source plot, $2 \mathrm{~m}$ in length, was planted with four RSD-infected stalks of LHo 83-153 before each spread plot, so that the harvester would always pass through an inoculum plot just prior to entering a spread plot. In addition, a buffer plot, $15.2 \mathrm{~m}$ in length, was planted with 20 stalks of RSD-free cane after each spread plot. One-meter gaps were left unplanted between all plots. The experiments were planted during early October 1993, and crops were grown using standard production practices.

A plant cane and two ratoon crops were obtained from the first experiment at each location. The experiments were harvested with single-row, mechanical, whole-stalk harvesters. The harvester always cut the inoculum source plots before the spread plots, so that the first two harvests served as disease spread events. Within plots, individual plants could not be reliably distinguished. Instead, prior to harvest, individual stalks were flagged with marking tape at the beginning and every $0.9 \mathrm{~m}$ through each plot, so that a total of 17 to 18 stalks were flagged. In addition, two stalks were flagged in each inoculum plot. After harvest, the stalks from the inoculum source and spread plots were collected, numbered sequentially, and used to assess RSD spread and increase.

A second experiment was conducted at each location to study the between-field spread and increase of RSD. At the harvest of the plant cane crop of the first experiment during October 1994, 20 stalks were collected sequentially at the beginning and every $0.75 \mathrm{~m}$ from each spread plot, and these stalks were sequentially planted in 
single-row plots, $15.2 \mathrm{~m}$ in length, as described above. Between-field spread and increase of disease was then determined at the end of the subsequent growing season by assessing disease in 17 to 18 stalks collected from the plant cane plots in the same manner as described above.

Determination of RSD spread and increase. Each collected stalk was assayed for RSD by five disease detection methods: alkaline-induced metaxylem autofluorescence (AIMA) (4); microscopic examination of xylem sap for bacteria (6); and three serological assays for $C$. xyli subsp. $x y l i$ : dot blot enzyme immunoassay (10), evaporative-binding enzyme immunoassay (EB-EIA) $(1,2)$, and tissue blot enzyme immunoassay (9). A stalk was considered to be infected with RSD if the results from at least three of the five detection methods were positive. RSD spread was determined as the furthest distance along the row that the pathogen was detected, and RSD increase was determined as the number of infected plants occurring within a plot. Spread and increase within fields were determined at the end of the first and second ratoon growing seasons. Between-field disease spread and increase were determined once at the end of the subsequent plant cane growing season.

Disease detection methods. AIMA is an indirect RSD assay based on the detection of a host reaction to infection in which the metaxylem vessel walls exhibit red autofluorescence when placed under alkaline conditions (4). For this assay, a stalk cross-section was removed from the growth ring in the upper portion of the lowest node collected, treated with $0.1 \mathrm{M}$ Tris (tris[hydroxymethyl]aminomethane), $\mathrm{pH} 10$, and observed with a compound fluorescence microscope at $\times 250$.

Microscopic examination of xylem sap for bacteria and the three immunoassays are direct pathogen detection methods. For microscopic examination of sap, xylem sap was collected from the lowest internode of each stalk by centrifugation at $4,000 \mathrm{rpm}$ for $5 \mathrm{~min}$. Sap was then placed on a microscope slide and observed with dark-field microscopy at $\times 500$ for the presence of characteristic bent, rod-shaped bacteria. Sap from a stalk known to be infected with RSD was used as a positive control for comparison.
The dot blot enzyme immunoassay was modified slightly from the method described previously (9). A 100- $\mu$ l sample of lower internode sap collected by centrifugation was added to a single well of a 96well manifold clamped over a membrane filter. The first antibody step used a polyclonal population prepared in a rabbit against $C$. xyli subsp. xyli, and the second antibody step used a polyclonal goat-antirabbit population conjugated with alkaline phosphatase. Results were determined by subjective visual observation of blue color development. Sap from RSD-infected and noninfected stalks were included as controls for comparison.

The EB-EIA was conducted as described previously with minor modifications (2). Xylem sap was collected from the lowest internode of each stalk by centrifugation as described above, and $200 \mu \mathrm{l}$ was added to a single well in a 96-well polystyrene microtiter plate. The first and second antibodies used were the same as for the dot blot. Sap from RSD-infected and noninfected stalks were included as positive and negative controls. Sap from noninfected stalks was placed in four wells per plate, and a positive reaction was determined as any well exhibiting an optical density at $405 \mathrm{~nm}$ of at least 1.5 times the absorbance mean for the negative control wells.

The tissue blot enzyme immunoassay was conducted as described previously (9). A transverse section of a 13-mm-diameter core removed longitudinally from a lower internode of each stalk was placed in a well of a template in direct contact with a nitrocellulose membrane and centrifuged at 3,000 rpm for $15 \mathrm{~min}$. The first and second antibodies were the same as for the dot blot and EB-EIA. A positive sample was determined by the visual observation of blue color development in at least one vascular bundle imprint on the membrane.

Comparison of detection methods. The accuracy of detection of $C$. xyli subsp. $x y l i$ infection in individual stalks was determined for each detection method by comparing the results for each of the five methods in each of the RSD spread and increase field experiments. The RSD detection results for first and second ratoon crops from the within-field spread and increase experiment, and the plant cane crop results from the between-field spread and increase experiment at the two locations were compared separately, and then the combined results for all six experiments were compared. If the result for a stalk with one detection method was in disagreement with at least three other methods, it was considered to be in error. A sample reading for a method indicating a positive detection of infection for a majority-rules, noninfected stalk was termed a "false positive." A sample reading for a method indicating no infection for a majority-rules, infected stalk was termed a "false negative." The detection methods were compared for the percentage frequencies of false positives and false negatives and for overall accuracy determined as the percent correct diagnosis of stalk infection status. Detection method false negative frequencies also were determined and compared for the 192 samples collected from the inoculum source plots.

Statistical analyses. Data were analyzed using the general linear model procedures of the Statistical Analysis System, Version 6.2 (SAS Institute, Cary, NC). Analyses were performed for the withinfield and between-field RSD spread and increase field experiments. Means for distance of disease spread along a row and number of infected plants per plot were then compared for the different cultivars using Fisher's least significant difference test at the $5 \%$ level of probability. RSD detection method results were compared for individual and combined experiments. Means were compared using Duncan's new multiple range test at the $5 \%$ level of probability.

\section{RESULTS}

Field spread and increase of RSD. The distance of spread of RSD along a row and the number of RSD-infected plants per plot determined after one mechanical harvest within a field in the first ratoon crop were greater at location one than at location two (Table 1). Disease spread and increase between fields determined in a secondplant cane crop were greater than withinfield spread at both locations. At location one, distance of RSD spread and number of infected plants per plot were 44 and

Table 1. Spread and increase of ratoon stunting disease (RSD) at two locations within a field in the first ratoon crop and between fields in a second plant cane crop ${ }^{\mathrm{x}}$

\begin{tabular}{|c|c|c|c|c|c|c|}
\hline \multirow[b]{2}{*}{ Experiment } & \multicolumn{3}{|c|}{ Distance of RSD spread along row $(\mathrm{m})^{\mathrm{y}}$} & \multicolumn{3}{|c|}{ No. of RSD-infected plants per plot $^{\mathrm{z}}$} \\
\hline & Location one & Location two & $P>F$ & Location one & Location two & $P>F$ \\
\hline Within field & 7.3 & 3.9 & 0.0017 & 4.3 & 1.7 & 0.0001 \\
\hline Between field & 10.5 & 7.9 & 0.5117 & 7.5 & 3.4 & 0.0012 \\
\hline$P>F$ & 0.0041 & 0.01 & & 0.0001 & 0.01 & \\
\hline
\end{tabular}


$74 \%$ greater, respectively, in the betweenfield experiment than within a field. Spread and increase of disease were 102 and $100 \%$ greater, respectively, between fields than within a field at location two. The number of infected plants also was greater at location one in the between-field experiments (Table 1).

In the combined analyses of the experiments, significant cultivar by location interactions for distance of disease spread and cultivar by location by field interactions for number of infected stalks were detected, so the results for individual cultivars are presented separately for the different experiments and locations (Tables 2 and 3 ). The greater amount of infection in the within- and between-field experiments at location one revealed differences among the cultivars. In first ratoon, the withinfield distance of disease spread and the incidence of infected plants were less for CP 72-370 and LCP 85-384 than for CP 70-321, CP 79-318, and LCP 82-89. The between-field spread of disease at location one was less in LCP 85-384 than in five other cultivars, and increase of disease was greater for LCP 82-89 than for all other cultivars. At location two, disease spread was less in CP 72-370 than in LHo 83-153, and disease incidence was less in $\mathrm{CP} 72$ 370 and CP 79-318 than in LCP 82-89.

The distance of RSD spread and number of infected plants per plot increased at both locations in second ratoon compared with first ratoon (Table 4). After a second harvest, within-field spread of RSD had increased $58 \%$, and the number of infected plants had increased $84 \%$ at location one. Disease spread and incidence increased 126 and $147 \%$, respectively, between first and second ratoon at location two. The distance of disease spread and number of infected plants were both greater at location one than location two in second ratoon (Table 4). Differences among cultivars also were detected in second ratoon. At location one, LCP 85-384 exhibited less disease spread than all other cultivars except $\mathrm{CP}$ 72-370 (Table 2) and lower disease incidence than all except CP $72-370$ and $\mathrm{CP}$

Table 2. Comparison of distance of ratoon stunting disease (RSD) spread along a row in eight sugarcane cultivars at two locations in within- and betweenfield spread experiments

\begin{tabular}{|c|c|c|c|c|c|c|}
\hline \multirow[b]{3}{*}{ Cultivar } & \multicolumn{4}{|c|}{ Within field } & & \\
\hline & \multicolumn{2}{|c|}{ Location one } & \multicolumn{2}{|c|}{ Location two } & \multicolumn{2}{|c|}{ Between field $^{z}$} \\
\hline & First ratoon & Second ratoon & First ratoon & Second ratoon & Location one & Location two \\
\hline CP 65-357 & $5.1 \mathrm{bc}$ & $11.4 \mathrm{ab}$ & $3.9 \mathrm{ab}$ & $5.1 \mathrm{ab}$ & $10.5 \mathrm{ab}$ & $12.3 \mathrm{a}$ \\
\hline CP 70-321 & $10.8 \mathrm{ab}$ & $12.6 \mathrm{a}$ & $4.5 \mathrm{ab}$ & $11.1 \mathrm{a}$ & $11.7 \mathrm{ab}$ & $10.5 \mathrm{a}$ \\
\hline CP 72-370 & $1.5 \mathrm{c}$ & $8.1 \mathrm{bc}$ & $0.3 \mathrm{~b}$ & $2.4 \mathrm{~b}$ & $8.7 \mathrm{abc}$ & $3.6 \mathrm{a}$ \\
\hline CP 79-318 & $10.8 \mathrm{ab}$ & $13.2 \mathrm{a}$ & $0.6 \mathrm{ab}$ & $6.0 \mathrm{ab}$ & $13.8 \mathrm{ab}$ & $5.1 \mathrm{a}$ \\
\hline LCP $82-89$ & $12.9 \mathrm{a}$ & $13.8 \mathrm{a}$ & $5.4 \mathrm{ab}$ & $11.1 \mathrm{a}$ & $14.4 \mathrm{a}$ & $6.6 \mathrm{a}$ \\
\hline LHo 83-153 & $6.9 \mathrm{abc}$ & $12.3 \mathrm{a}$ & $8.4 \mathrm{a}$ & $7.5 \mathrm{ab}$ & $8.1 \mathrm{bc}$ & $9.1 \mathrm{a}$ \\
\hline LCP 85-384 & $2.1 \mathrm{c}$ & $6.9 \mathrm{c}$ & $2.7 \mathrm{ab}$ & $8.5 \mathrm{ab}$ & $4.2 \mathrm{c}$ & $8.1 \mathrm{a}$ \\
\hline НоСР 85-845 & $7.2 \mathrm{abc}$ & $12.3 \mathrm{a}$ & $6.0 \mathrm{ab}$ & $9.6 \mathrm{a}$ & $11.1 \mathrm{ab}$ & $7.5 \mathrm{a}$ \\
\hline
\end{tabular}

${ }^{y}$ Distance ( $\mathrm{m}$ ) of RSD spread along a row within a field was determined after one mechanical harvest in the first ratoon crop and after two harvests in the second ratoon crop by sampling plants every $0.9 \mathrm{~m}$ in $15.2-\mathrm{m}$, single-row plots. Distance means within columns followed by the same letter were not significantly different $(P=0.05)$ as determined by Fisher's least significant difference test.

${ }^{\mathrm{z}}$ Distance (m) of RSD spread between two fields was determined in a second plant cane (first year) crop grown from stalks collected after one mechanical harvest by sampling plants every $0.9 \mathrm{~m}$ in $15.2-\mathrm{m}$, single-row plots. Distance means within columns followed by the same letter were not different $(P=$ $0.05)$ as determined by Fisher's least significant difference test.

Table 3. Comparison of increase of ratoon stunting disease (RSD) incidence along a row in eight sugarcane cultivars at two locations in within- and between-field increase experiments

\begin{tabular}{|c|c|c|c|c|c|c|}
\hline \multirow[b]{3}{*}{ Cultivar } & \multicolumn{4}{|c|}{ Within field ${ }^{\mathrm{z}}$} & & \\
\hline & \multicolumn{2}{|c|}{ Location one } & \multicolumn{2}{|c|}{ Location two } & \multicolumn{2}{|c|}{ Between field $^{z}$} \\
\hline & First ratoon & Second ratoon & First ratoon & Second ratoon & Location one & Location two \\
\hline CP 65-357 & $4.3 \mathrm{abc}$ & $7.3 \mathrm{cde}$ & $1.7 \mathrm{ab}$ & $2.7 \mathrm{bc}$ & $6.0 \mathrm{bcd}$ & $4.7 \mathrm{a}$ \\
\hline CP 70-321 & $6.3 \mathrm{a}$ & $10.0 \mathrm{abc}$ & $1.7 \mathrm{ab}$ & $5.0 \mathrm{ab}$ & $8.0 \mathrm{bc}$ & $4.0 \mathrm{a}$ \\
\hline CP 72-370 & $1.7 \mathrm{c}$ & $5.7 \mathrm{de}$ & $0.3 \mathrm{~b}$ & $2.0 \mathrm{c}$ & $6.7 \mathrm{bcd}$ & $1.3 \mathrm{a}$ \\
\hline CP 79-318 & $7.0 \mathrm{a}$ & $11.7 \mathrm{ab}$ & $0.7 \mathrm{~b}$ & $3.7 \mathrm{bc}$ & $9.3 \mathrm{~b}$ & $2.3 \mathrm{a}$ \\
\hline LCP $82-89$ & $5.3 \mathrm{a}$ & $12.7 \mathrm{a}$ & $4.0 \mathrm{a}$ & $6.7 \mathrm{a}$ & $15.7 \mathrm{a}$ & $5.0 \mathrm{a}$ \\
\hline LHo 83-153 & $4.0 \mathrm{abc}$ & $9.7 \mathrm{abc}$ & $2.0 \mathrm{ab}$ & $3.7 \mathrm{bc}$ & $5.0 \mathrm{~cd}$ & $3.0 \mathrm{a}$ \\
\hline LCP 85-384 & $2.0 \mathrm{bc}$ & $4.3 \mathrm{e}$ & $2.0 \mathrm{ab}$ & $5.3 \mathrm{ab}$ & $2.7 \mathrm{~d}$ & $2.7 \mathrm{a}$ \\
\hline НоСР 85-845 & $4.0 \mathrm{abc}$ & $9.0 \mathrm{bcd}$ & $1.7 \mathrm{ab}$ & $4.0 \mathrm{abc}$ & $6.7 \mathrm{bcd}$ & $2.3 \mathrm{a}$ \\
\hline
\end{tabular}

${ }^{\mathrm{z}}$ Increase of RSD incidence was determined as the number of infected plants detected from plants sampled every $0.9 \mathrm{~m}$ in 15.2 - $\mathrm{m}$, single-row plots. Increase within a field was determined after one mechanical harvest in the first ratoon crop and after two harvests in the second ratoon crop. Between-field increase was determined in a second plant cane (first year) crop grown from stalks collected after the first harvest. Infected plant means within columns followed by the same letter were not different $(P=0.05)$ as determined by Fisher's least significant difference test.

Table 4. Spread and increase of ratoon stunting disease (RSD) detected at two locations in the sugarcane ratoon crops following the first and second mechanical harvests

\begin{tabular}{|c|c|c|c|c|c|c|}
\hline \multirow[b]{2}{*}{ Crop year } & \multicolumn{3}{|c|}{ Distance of RSD spread along row $(\mathrm{m})^{\mathrm{y}}$} & \multicolumn{3}{|c|}{ No. of RSD-infected plants per plot ${ }^{\mathrm{Z}}$} \\
\hline & Location one & Location two & $P>F$ & Location one & Location two & $P>F$ \\
\hline First ratoon & 7.3 & 3.9 & 0.0017 & 4.3 & 1.7 & 0.0001 \\
\hline Second ratoon & 11.5 & 8.8 & 0.0002 & 7.9 & 4.2 & 0.0001 \\
\hline$P>F$ & 0.0001 & 0.0014 & & 0.0001 & 0.0001 & \\
\hline
\end{tabular}

${ }^{y}$ Spread of RSD was determined as the greatest distance along a row that an infected plant was detected from plants sampled every $0.9 \mathrm{~m}$ in 15.2 -m, single-row plots. Means are for eight cultivars combined.

z RSD increase was determined as the number of infected plants detected from plants sampled every $0.9 \mathrm{~m}$ in 15.2 -m, single-row plots. Means are for eight cultivars combined. 
65-357 (Table 3). At location two, CP 72370 exhibited less disease spread than $\mathrm{CP}$ 70-321, LCP 82-89, and HoCP 85-845 (Table 2) and lower incidence than CP 70321, LCP 82-89, and LCP 85-384 (Table $3)$.

Comparison of RSD detection methods. The frequency of false positives for the five detection methods ranged from 4 to $24 \%$ for the combined results from RSD spread and increase field experiments (Table 5). All methods were similar to each other, except the false positive error frequency was higher for AIMA. Variability was detected among the five methods in false positive frequency when the results of samples collected from the different crops and locations of the field experiments were considered as six separate experiments. The frequency of false positives ranged from 8 to $49 \%$ for AIMA and from 3 to $21 \%$ for dot blot in the different experiments. Dot blot had a higher false positive frequency than the other methods in one experiment.

The false negative error frequency was lowest for AIMA, dark-field microscopy, and tissue blot in all experiments combined (Table 6). The frequency of occurrence of false negatives for the five detection methods ranged from 3 to $21 \%$. Variability also was detected among the five methods in false negative error frequency in different experiments. The frequency of false negatives ranged from 9 to $33 \%$ for EB-EIA and from 9 to $34 \%$ for dot blot. When the 192 samples from the inoculum source plots were considered separately, the statistical relationships among the detection methods were the same as when all col- lected samples were considered. The false negative frequencies for AIMA, dark-field microscopy, dot blot, EB-EIA, and tissue blot were $2,3,14,9$, and $1 \%$, respectively.

The total accuracy of RSD detection was greatest for the tissue blot method (Table 7). Total accuracy ranged from 85 to $96 \%$ for the five methods in all experiments combined and from 75 to $99 \%$ across all methods and individual experiments. Variability was detected among the five methods in total accuracy of RSD detection in different experiments. AIMA was the least accurate method in two of six experiments, and dot blot was the least accurate method in two of six experiments.

\section{DISCUSSION}

Ratoon stunting disease can be spread and increased in planting material, or me-

Table 5. Frequencies of false-positive errors for five ratoon stunting disease (RSD) detection methods in six experiments

\begin{tabular}{|c|c|c|c|c|c|c|c|}
\hline \multirow[b]{2}{*}{ Detection method ${ }^{y}$} & \multicolumn{7}{|c|}{ False-positive frequency $(\%)^{\mathrm{z}}$} \\
\hline & Exp. 1 & Exp. 2 & Exp. 3 & Exp. 4 & Exp. 5 & Exp. 6 & Combined \\
\hline AIMA & $8 \mathrm{a}$ & $48 \mathrm{a}$ & $16 \mathrm{a}$ & $10 \mathrm{ab}$ & $49 \mathrm{a}$ & $10 \mathrm{~b}$ & $24 \mathrm{a}$ \\
\hline Dark-field & $6 a$ & $4 \mathrm{~b}$ & $10 a b$ & $8 \mathrm{~b}$ & $4 \mathrm{~b}$ & $9 \mathrm{~b}$ & $7 \mathrm{~b}$ \\
\hline Dot blot & $3 \mathrm{~b}$ & $11 \mathrm{~b}$ & $4 \mathrm{bc}$ & $17 \mathrm{a}$ & $13 \mathrm{~b}$ & $21 \mathrm{a}$ & $11 \mathrm{~b}$ \\
\hline EB-EIA & $2 \mathrm{~b}$ & $4 \mathrm{~b}$ & $2 \mathrm{c}$ & $5 \mathrm{bc}$ & $6 \mathrm{~b}$ & $6 \mathrm{bc}$ & $4 \mathrm{~b}$ \\
\hline Tissue blot & $7 \mathrm{a}$ & $10 \mathrm{~b}$ & $1 \mathrm{c}$ & $2 \mathrm{c}$ & $7 \mathrm{~b}$ & $1 \mathrm{c}$ & $5 \mathrm{~b}$ \\
\hline
\end{tabular}

y Methods compared were alkaline-induced metaxylem autofluorescence (AIMA), examination of xylem sap for bacteria with dark-field microscopy, dot blot enzyme immunoassay, evaporative-binding enzyme immunoassay (EB-EIA), and tissue-blot enzyme-immunoassay.

${ }^{\mathrm{z}}$ A false-positive error for a method was recorded if a positive detection of RSD was indicated for a noninfected sugarcane stalk. Frequencies were calculated as percentage of total stalk samples that were false-positive errors. Experiments 1 to 6 are results of RSD detection in xylem sap of stalks from a within-field spread and increase experiment at two locations in first and second ratoons and a between-field spread and increase experiment in plant cane at two locations, respectively. Means within a column followed by the same letter were not significantly different $(P=0.05)$ as determined by Duncan's new multiple range test.

Table 6. Frequencies of false-negative errors for five ratoon stunting disease (RSD) detection methods in six experiments

\begin{tabular}{lccccccc}
\hline & \multicolumn{7}{c}{ False-negative frequency $(\boldsymbol{\%})^{\mathbf{z}}$} \\
\cline { 2 - 7 } Detection method $^{\mathbf{y}}$ & Exp. 1 & Exp. 2 & Exp. 3 & Exp. 4 & Exp. 5 & Exp. 6 & Combined \\
\hline AIMA & $7 \mathrm{~b}$ & $1 \mathrm{~b}$ & $2 \mathrm{~b}$ & $0 \mathrm{c}$ & $16 \mathrm{ab}$ & $15 \mathrm{bc}$ & $7 \mathrm{~b}$ \\
Dark-field & $6 \mathrm{~b}$ & $9 \mathrm{~b}$ & $8 \mathrm{ab}$ & $1 \mathrm{bc}$ & $5 \mathrm{bc}$ & $7 \mathrm{bc}$ & $6 \mathrm{~b}$ \\
Dot blot & $22 \mathrm{a}$ & $10 \mathrm{~b}$ & $9 \mathrm{~b}$ & $20 \mathrm{a}$ & $33 \mathrm{a}$ & $34 \mathrm{a}$ & $21 \mathrm{a}$ \\
EB-EIA & $33 \mathrm{a}$ & $24 \mathrm{a}$ & $15 \mathrm{a}$ & $9 \mathrm{~b}$ & $22 \mathrm{ab}$ & $21 \mathrm{ab}$ & $21 \mathrm{a}$ \\
Tissue blot & $0 \mathrm{c}$ & $5 \mathrm{~b}$ & $6 \mathrm{~b}$ & $3 \mathrm{bc}$ & $0 \mathrm{c}$ & $2 \mathrm{c}$ & $3 \mathrm{~b}$ \\
\hline
\end{tabular}

${ }^{y}$ Methods compared were alkaline-induced metaxylem autofluorescence (AIMA), examination of xylem sap for bacteria with dark-field microscopy, dot blot enzyme immunoassay, evaporative-binding enzyme immunoassay (EB-EIA), and tissue blot enzyme immunoassay.

${ }^{\mathrm{z}} \mathrm{A}$ false-negative error for a method was recorded if a negative detection of RSD was indicated for an infected stalk. Frequencies were calculated as percentage of total stalk samples that were false-negative errors. Experiments 1 to 6 are results of RSD detection in xylem sap of stalks from a within-field spread and increase experiment at two locations in first and second ratoons and a between-field spread and increase experiment in plant cane at two locations, respectively. Means within a column followed by the same letter were not significantly different $(P=0.05)$ as determined by Duncan's new multiple range test.

Table 7. Comparison of accuracy of detection of ratoon stunting disease (RSD) by five detection methods in six experiments

\begin{tabular}{|c|c|c|c|c|c|c|c|}
\hline \multirow[b]{2}{*}{ Detection methody } & \multicolumn{7}{|c|}{ Accuracy of RSD detection $(\%)^{\mathrm{z}}$} \\
\hline & Exp. 1 & Exp. 2 & Exp. 3 & Exp. 4 & Exp. 5 & Exp. 6 & Combined \\
\hline AIMA & $93 \mathrm{a}$ & $75 \mathrm{~b}$ & $75 \mathrm{~b}$ & $88 \mathrm{c}$ & $89 \mathrm{~b}$ & $89 \mathrm{~b}$ & $85 \mathrm{c}$ \\
\hline Dark-field & $94 \mathrm{a}$ & $93 \mathrm{a}$ & $93 \mathrm{a}$ & $92 \mathrm{bc}$ & $93 \mathrm{~b}$ & $92 \mathrm{~b}$ & $93 \mathrm{~b}$ \\
\hline Dot blot & $91 \mathrm{ab}$ & $89 a$ & $88 \mathrm{a}$ & $93 \mathrm{bc}$ & $82 \mathrm{c}$ & $80 \mathrm{c}$ & $87 \mathrm{bc}$ \\
\hline EB-EIA & $87 \mathrm{~b}$ & $88 \mathrm{a}$ & $90 \mathrm{a}$ & $96 a b$ & $93 \mathrm{~b}$ & $92 \mathrm{~b}$ & $91 \mathrm{bc}$ \\
\hline Tissue blot & $95 \mathrm{a}$ & $94 \mathrm{a}$ & $94 \mathrm{a}$ & $98 \mathrm{a}$ & $99 \mathrm{a}$ & $99 \mathrm{a}$ & $96 \mathrm{a}$ \\
\hline
\end{tabular}

y The five RSD detection methods compared were alkaline-induced metaxylem autofluorescence (AIMA), examination of xylem sap for bacteria with dark-field microscopy, dot blot enzyme immunoassay, evaporative-binding enzyme immunoassay, and tissue blot enzyme immunoassay.

${ }^{z}$ The accuracy of RSD detection was determined as the percentage of correct identifications of both infected and noninfected sugarcane stalks. Experiments 1 to 6 are the results of RSD detection in xylem sap of stalks from a within-field spread and increase experiment at two locations in first and second ratoons and a between-field spread and increase experiment in plant cane at two locations, respectively. Means within a column followed by the same letter were not different $(P=0.05)$ as determined by Duncan's new multiple range test. 
chanically, by the transfer of sap on the surfaces of equipment from an infected plant to a wounded, noninfected plant. The lack of external symptoms other than stunting or reliable internal symptoms has made it difficult to obtain information concerning rates of disease spread and increase. In this study, differences were detected in RSD spread and increase following mechanical harvest among cultivars, between locations, and in ratoon growth compared with plants grown from harvested stalks. Previous studies utilized different methods and obtained variable results $(3,5,7,13)$. Initial experiments were conducted before the causal agent was known $(5,7)$, and infection was determined from the observation of internal symptoms since shown to be unreliable $(7,12)$. In a study using microscopic examination of sap to detect infection, 4.3 of the first seven plants in harvested spread plots were found to be infected, with additional intermittent infections detected in up to 35 plants along the row (13). Information on cultivar susceptibility was only provided in one study (3), and large differences were detected among cultivars in RSD spread and increase. In that study, four RSD-infected plants were detected in CP 65-357 using AIMA out of 40 plants sampled every $0.3 \mathrm{~m}$ in a $12-\mathrm{m}$, single-row plot after one harvest. In second ratoon, the number of infected plants increased to 10.4 per plot. Considering the threefold difference in sampling intensity with distance, these results are similar to the current study results for CP 65-357 at location two.

The current study confirms that cultivars vary in susceptibility to spread and increase of RSD. All of the included cultivars are rated as moderately to highly susceptible to yield loss due to RSD, except for CP 79-318 (M. P. Grisham, unpublished). This cultivar becomes infected when inoculated, but it does not exhibit yield loss. However, CP 79-318 was in the group of cultivars exhibiting the greatest susceptibility to disease spread and increase. The stunting, caused by RSD, is affected by environmental conditions as well as host genotype (8). As a result, yield loss detected in inoculated tests is variable. Additional variability among host genotypes apparently also exists in susceptibility to spread and increase of RSD that is not always consistent with susceptibility to stunting.

The differences in RSD spread and increase detected between locations indicate that these epidemiological parameters can vary under different conditions. Factors that could be important include inoculum concentration and environmental conditions. The previous study in Louisiana demonstrated that inoculum concentration can affect the rates of disease spread and increase (3). The inoculum source plots in the current study were established simi- larly, but no effort was made to compare bacterial titer in the plants at the two locations. However, the test results from two stalks collected from each inoculum source plot indicated that the plants were infected. The bases of stalks of plants remaining after harvest that may have been inoculated with sap from infected plants were exposed to prevailing weather conditions. Environmental factors were not monitored at both locations, so it is uncertain whether variable conditions occurred between locations that might have affected infection efficiency.

An early study found that the increase of RSD incidence was greater in plant cane established with harvested stalks than in the ratoon growth of the harvested field (5). The current results confirm that RSD spread and increase are greatest when harvested stalks are planted. As mentioned above, within harvested fields, wounded plant surfaces inoculated with sap consist of cut stalk bases that are exposed to the weather. Mechanical, whole-stalk harvesters cut stalks twice, at the base and below the top of the stalk. In addition, handling chains may cause puncture wounds in the stalk rind as stalks pass through the machine. Thus, harvested stalks have multiple opportunities for inoculation, and covering of stalks at planting with soil creates environmental conditions different than those experienced by plant stubble remaining after harvest. The results indicate that the greatest threat of spread and increase of RSD occurs at planting.

Determining the spread and increase of RSD in the study required the detection of the pathogen in xylem sap collected from each stalk. At the time the experiments were conducted, it was not known which method would give the most accurate detection results. No method is error free. The utilization of multiple detection methods using a majority-rules approach could give greater confidence in the determination of infection status for any sample, and it provided the opportunity to compare the detection accuracy of five different methods. However, problems could occur if the methods employed varied greatly in detection accuracy. Two outcomes from this study support the utilization of a majority rules approach to determine sample infection status and compare detection method accuracy. Sample infection status was determined by agreement of either four or five of five methods $86 \%$ of the time for positive samples and $91 \%$ of the time for negative samples. In addition, the inoculum source plots provided samples that could be expected to be positive, and the results for false negative frequencies for the different methods within this sample subset were similar to the results for all samples combined.

A sensitive, reliable RSD detection method would allow monitoring of the disease and result in improved disease management. The accuracy of detection of RSD has been determined previously for various methods $(2,4,6,9,10)$. The methods chosen for comparison in this study were ones with potential for application in largescale testing. The tissue blot assay was previously shown to be more accurate than the dot blot assay (10). In this study, it was more accurate than the other four methods. A comparison of false negative error frequencies indicated that the dot blot and EB-EIA methods were less sensitive than the others. AIMA was least accurate in correctly identifying noninfected stalks. AIMA exhibited a high degree and the dot blot a lesser degree of variability between experiments in both false positive and negative error frequencies. The EB-EIA exhibited variability in false negative frequency. Dark-field microscopy and the tissue blot were more consistent across experiments. Microscopic examination of sap and recognition of the correct bacterial cell type probably require the greatest level of expertise, and RSD detection accuracy could therefore be operator dependent. The tissue blot is the only method that would require that stalk tissue be delivered and sampled in the lab. However, of the methods compared, the tissue blot enzyme immunoassay provides the greatest accuracy in RSD detection.

\section{ACKNOWLEDGMENTS}

We thank L. B. Grelen, K. Warnke, and Z. Yin for technical and data analysis assistance.

\section{LITERATURE CITED}

1. Comstock, J. C., and Irey, M. S. 1992. Detection of the sugarcane leaf scald pathogen, Xanthomonas albilineans, using tissue blot immunoassay, ELISA, and isolation techniques. Plant Dis. 76:1033-1035.

2. Croft, B. J., Greet, A. D., Leaman, T. M., and Teakle, D. S. 1994. RSD diagnosis and varietal resistance screening in sugarcane using the EB-EIA technique. Aust. Soc. Sugar Cane Technol. 16:143-151.

3. Damann, K. E. 1992. Effect of sugarcane cultivar susceptibility on spread of ratoon stunting disease by the mechanical harvester. Plant Dis. 76:1148-1149.

4. Damann, K. E., Jr. 1988. Alkaline-induced metaxylem autofluorescence: A diagnostic symptom of ratoon stunting disease of sugarcane. Phytopathology 78:233-236.

5. Forbes, I. L., Steib, R. J., and Chilton, S. J. P. 1960. Ratoon stunting disease of sugarcane. La. Agric. Exp. Stn. Bull. 532.

6. Gillaspie, A. G., Jr., Davis, R. E., and Worley, J. F. 1973. Diagnosis of ratoon stunting disease based on the presence of a specific microorganism. Plant Dis. Rep. 57:987-990.

7. Gillaspie, A. G., Jr., and Teakle, D. S. 1989. Ratoon stunting disease. Pages 59-80 in: Diseases of Sugarcane - Major Diseases. C. Ricaud, B. T. Egan, A. G. Gillaspie, Jr., and C. G. Hughes, eds. Elsevier, New York.

8. Grisham, M. P. 1991. Effect of ratoon stunting disease on yield of sugarcane grown in multiple three-year plantings. Phytopathology 81:337-340.

9. Harrison, N. A., and Davis, M. J. 1988. Colonization of vascular tissues by Clavibacter $x y l i$ subsp. $x y l i$ in stalks of sugarcane cultivars differing in susceptibility to ratoon stunting 
disease. Phytopathology 78:722-727.

10. Harrison, N. A., and Davis, M. J. 1990. Comparison of serological techniques for diagnosis of ratoon stunting disease. Sugar Cane, Spring Suppl. 5-9.

11. Hoy, J. W., Grisham, M. P., and Damann, K.
E. 1997. Ratoon stunting disease (RSD) spread and increase and reliability of five RSD detection methods. (Abstr.) Phytopathology 87:S44.

12. Irvine, J. E. 1976. Factors affecting the expression of juvenile symptoms of the ratoon stunting disease. Proc. Am. Soc. Sugar Cane Technol. 5(New ser.):109-113.

13. Taylor, P. W. J., Ryan, C. C., and Birch, R. G. 1988. Harvester transmission of leaf scald and ratoon stunting disease. Sugar Cane 1988, No. 4:11-14. 